\title{
Can an average THI from 70 to 72 in the Summer Affect Behaviour, Physiology, Performance, and Carcass Weight in Feedlot Steers?
}

Maria Eugênia Andrighetto Canozzi ( $\square$ mecanozzi@inia.org.uy )

Instituto Nacional de Investigacion Agropecuaria https://orcid.org/0000-0001-9263-8113

Juan Manuel Clariget

Instituto Nacional de Investigacion Agropecuaria

Gonzalo Roig

MARFRIG GROUP

\section{Eduardo Pérez}

Instituto Nacional de Investigacion Agropecuaria

Valentín Aznárez

MARFRIG Group

\section{Georgget Banchero}

Instituto Nacional de Investigacion Agropecuaria

\section{Alejandro La Manna}

Instituto Nacional de Investigacion Agropecuaria

\section{Research Article}

Keywords: ADG, beef cattle, efficiency, heat stress, temperature

Posted Date: September 24th, 2021

DOl: https://doi.org/10.21203/rs.3.rs-834321/v1

License: (9) This work is licensed under a Creative Commons Attribution 4.0 International License. Read Full License 


\section{Abstract}

Environmental conditions during hot weather can decrease feed intake and cattle growth. This study conducted over three consecutive years (Trial 1,2, and 3), in the same feedlot facility, evaluated access to shade as a strategy to mitigate heat stress of cattle finished during summer in Uruguay. Each year, 32 Bos taurus and/or Bos traurus crossbred steers (initially weighing $461 \pm 28 \mathrm{~kg}$ ) were blocked and assigned to one of eight pens (4 animals/pen), where one of two treatments were applied -no shade or shade access. Twenty-four pens were considered in a randomized complete block design. For Trial 1, 2, and 3 , respectively, the average $\mathrm{THI}$ was 71,72 , and 70 . Steers with access to shade had greater daily dry matter intake $(P=0.003)$, average daily gain $(P=0.004)$, final live weight $(P=0.04)$, feed: gain ratio $(P=$ $0.05)$, and slaughter weight $(P=0.02)$ than no shaded steers. Ruminal pH was higher $(P<0.0001)$ in shaded than in no shaded animals. The average respiration rate and panting score was lower $(\mathrm{P}<$ $0.0001)$ for shaded than for no shaded steers, except in the early morning. Access to shade increased the time spent of animals feeding $(P=0.008)$ and ruminating $(P=0.001)$, decreasing inactive time $(P<$ $0.0001)$. We concluded that shade could improve performance and welfare of feedlot cattle during summertime even in regions with an average THI from 70 to 72 .

\section{Introduction}

Around the world, fattening cattle in outdoor feedlots is becoming more common, and large ones can be found in North America, South America, and Australia (Grandin, 2016). Cattle under this condition, fed with high energy diets, unable to escape from their environment, are candidates for heat stress (Blackshaw and Blackshaw, 1994; Grandin, 2016; Summer et al., 2019). Heat stress occurs when environmental conditions exceeds the upper critical temperature of a given specie (Armstrong, 1994; Blackshaw and Blackshaw, 1994; Collier et al., 2019), resulting from a total heat load exceeding the capacity for heat dissipation (Bernabucci et al., 2010). Furthermore, the temperature humidity index (THI), developed by Thom (1959), is typically reported and used in the livestock area (Brown-Brandl, 2008); according to this Index, Livestock Weather Safety Index (LWSI) quantitates the heat stress level in normal, alert, danger, and emergency ( $\mathrm{LCl}, 1970)$. The physiological imbalance induced by changes of environmental factors, animal characteristics, and thermoregulatory mechanisms provokes economical losses, including decrease in performance and increase in mortality (Silanikove, 2000; St. Pierre et al., 2003).

A variety of animal measurements have been used to indicate heat stress and can include morphological, behavioural, physiological, neuroendocrine, blood biochemical, metabolic, cellular, and molecular responses (Sejian et al., 2018). Respiration rate observation, which should be measured in conjunction with panting observation (Silanikove, 2000; Gaughan et al., 2002), is practical and immediately increases under thermal stress (Blackshaw and Blackshaw, 1994; Mitlöhner et al., 2001 a; Brown-Brandl et al., 2003). Dry matter intake decreases (Hahn and Nienaber, 1993; Mader et al., 1999a; Gaughan et al., 2002; BrownBrandl et al., 2003; Hagenmaier et al., 2016) or is not affected (Barajas et al., 2009; Blaine and Nsahlai, 
decrease feeding behaviour (Mitlöhner et al., 2002; Lees et al., 2020), average daily gain (Mitlöhner et al., 2002; Koknaroglu et al., 2008; Barajas et al., 2013), and hot carcass weight (Mitlöhner et al., 2001a; Barajas et al., 2009; Blaine and Nsahlai, 2011).

Strategies to mitigate heat stress on feedlot cattle involve physical modification of the environment, such as the use of sprinklers or shade (Fuquay, 1981; Morrison, 1983; Mader, 2003; Lees et al., 2019); and, according to climate area, one strategy can be more effective than another. In regions with high humidity during the hottest months, is common to apply water on the animal or to the pen, which can be beneficial; however, adverse effects, such as cattle acclimation and elevated relative humidity in the pen, should be considered (Mader, 2014). On the other hand, shade serves to reduce the amount of radiation imposed to the animal, being more effective than any other method in reducing heat stress production losses and deaths in cattle, as well relatively straightforward to implement (Morrison, 1983; Blackshaw and Blackshaw, 1994; Mader, 2014). A simple shade over an animal can reduce the radiation heat load by 45\% (Hahn et al., 1963), and helped to diminish the cattle deaths and economic losses in West Central lowa, USA (Busby and Loy, 1995).

A considerable variation in the performance of cattle across feedlot studies has been observed, consequence of hot environmental conditions and cattle management (Lees et al., 2019), like feedlot location, heat loads (duration, magnitude, degree of recovering), cattle genotype, body condition, time of feeding, housing, and shade characteristics (orientation, material, design, area of shade). Moreover, possible acclimation and compensatory production after stress relief must be considered (Morrison, 1983; Mitlöhner et al., 2001a). During an extreme event, the impact is variable between individuals even within the same feedlot (Brown-Brandl, 2008).

Information about shade benefits for cattle naturally exposed during finishing-time to hot environmental on feedlot performance in regions with an average THI of 72 or lower is scarce; therefore, alternative management practices for ameliorating heat stress need to be investigated (Sejian et al., 2018). Additionally, the use of shade is not common in Uruguay (Banchero et al., 2016), probably because it is not seeming to be cost-effective. For this reason, we stated the hypothesis that the performance and physiology aspects of finishing steers with access to shade will be better to those of steers with no access to shade during summer in a humid subtropical area. Our objective was to determine the effects of shade on behaviour, physiology, performance, and carcass traits of finishing beef steers during hot summer months in Uruguay, where average $\mathrm{THI}$ is between 70 and 72 .

\section{Material And Methods}

The effects of shade on finishing cattle in outdoor feedlots were measured in three consecutive years, during the summers of 2017 (Trial 1), 2018 (Trial 2), and 2019 (Trial 3).

\section{Location}


The trials were carried out on the same commercial feedlot $\left(33^{\circ} 12^{\prime} 20^{\prime \prime} S\right.$ latitude and $58^{\circ} 05^{\prime} 47^{\prime \prime} \mathrm{W}$ longitude), in Río Negro department, Uruguay. The feedlot facility is situated $14 \mathrm{~m}$ above sea level. This country has a humid subtropical climate, with mild winters, hot summers, and the precipitation (averaged annual: $1,000-1,400 \mathrm{~mm}$ ) is evenly distributed throughout the year (Cfa according to the Köppen-Geiger climate classification).

\section{Animals}

All procedures involving animal care and management were approved by the Committee for the Ethical Use of Animals of the National Institute of Agricultural Research (Protocol number 2016.53). Three feedlot growth-performance trials involving 96 Bos taurus and Bos taurus crossbred steers were conducted.

\section{Experimental procedures}

The same eight pens were used on every trial and they all had a compacted soil-surfaced and a pen area of $20 \mathrm{~m}^{2}$ /animal. Fences were built with wooden logs and secured to the soil. A concrete feed bunk covered the entire length of one side of the pen, allowing $1.25 \mathrm{~m}$ of bunk space/animal. The water trough, with float-activated water supply, was located along the portioning fence. Both feed bunk and water though allowed steers access to feed and water all times.

Upon arrive at the feedlot, steers were vaccinated for Clostridial diseases (Sintoxan, Merial, Lyon, France) and for viral diseases (Alliance Respiratoria, Merial, Lyon, France) and treated for gastrointestinal nematodes (Ivomec, Boehringer Ingelheim, Ingelheim, Germany, and Fasimec, Elanco, Greenfield, IN). During the adaptation period, steers were individually weighed, ear-tagged for identification, and randomly assigned to one of two treatments - i. control with no shade or ii. shade access, with four pens assigned to each treatment in each trial.

Animals were then placed in the experimental pens (four steers/pen), where they stayed for 14 days to adapt to a high-concentrate diet and to the daily management. Four pens were shaded with an artificial structure, constructed with timber and galvanised steel (100\%effective in reducing gradient heat load, 4.5 $\mathrm{m}^{2}$ of shade per animal, oriented north-south, and $4 \mathrm{~m}$ high). All cattle within a pen were able to access the shade at the same time. Neither feed bunks nor water troughs were beneath the shade.

Feed was offered three times per day, at 6:30 am, 9:30 am, and 3:30 pm. The first meal provided 25\% of the diet; the second meal, 35\%; and the last one, 40\%. Diet adjustment was performed every day, before the first meal, based on slick bunk management (scale 1 to $5 ; 1=$ slick bunk, $5=$ full bunk) (SchwartzkopfGenswein et al., 2003; Schutz et al., 2011).

Diets were sampled weekly, pooled per month, and sent to the Nutrition Laboratory of INIA La Estanzuela to perform chemical composition analysis (Table 1). Dry matter content was obtained by drying the diets in a forced-air oven $\left(60^{\circ} \mathrm{C}\right.$ for $\left.48 \mathrm{~h}\right)$ (Harris, 1970) and the percentage was determined by the equation (dry

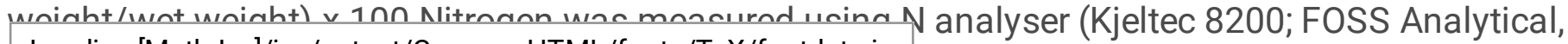
Loading [MathJax]/jax/output/CommonHTML/fonts/TeX/fontdata.js 
Hillerod, Denmark) to calculate CP as N x 6.25 (AOAC, 1990; Method 967.03). Ash was determined by AOAC (1990; Method 942.05). Concentrations of neutral and acid detergent fibre, both corrected for ash, were obtained using Ankom fiber analyser (ANKOM-2000l; ANKOM Technology, Macedon NY, United States) using Van Soest et al. (1991) technique. Lignin was determined according to Georing and Van Soest (1970). Ether extract was obtained by ANKOM-XT15 (ANKOM Technology, Macedon NY, United States) according to AOAC (1990; Method 954.02). Metabolizable energy of the diet was estimated based on theorical ME for each ingredient reported by NASEM (2016).

Table 1

Composition of finishing diets used in each trial

\begin{tabular}{|c|c|c|c|}
\hline Item & Trial 1 & Trial 2 & Trial 3 \\
\hline \multicolumn{4}{|l|}{ Feed ingredient ${ }^{1}$} \\
\hline Barley grain & 34.0 & 21.8 & - \\
\hline Wheat grain & - & 22.2 & 27.5 \\
\hline Corn steam-flaked & 25.5 & 17.6 & 34.4 \\
\hline Oat grain & 10.8 & 12.8 & 13.4 \\
\hline Corn DDGS & 8.9 & 9.2 & 5.1 \\
\hline Eucalyptus wood chip & 8.9 & 8.2 & - \\
\hline Eucalyptus bark & - & - & 8.0 \\
\hline Soybean meal & 2.4 & 5.5 & 7.8 \\
\hline Soybean hull & 6.8 & - & - \\
\hline Supplement premix & 2.6 & 2.7 & 3.8 \\
\hline \multicolumn{4}{|l|}{ Chemical composition } \\
\hline Dry matter (\%) & 77.3 & 79.7 & 78.3 \\
\hline Crude protein (\%) & 13.3 & 18.1 & 17.2 \\
\hline Ash (\%) & 6.0 & 5.4 & 10.0 \\
\hline Neutral detergent fibre (\%) & 43.8 & 34.2 & 35.5 \\
\hline Acid detergent fibre (\%) & 27.2 & 18.3 & 20.0 \\
\hline Lignin (\%) & 6.5 & 1.2 & 7.2 \\
\hline Ether extract (\%) & 3.7 & 3.6 & 3.2 \\
\hline Metabolizable energy (Mcal/kg DM) & 2.74 & 2.81 & 2.84 \\
\hline
\end{tabular}


Trial 1. The experimental phase took place from February 3rd to April 9th, 2017 (65-d on feed). A total of 32 steers (24 Aberdeen Angus and eight Angus $x$ Hereford crosses), with 24 month of age and an average weight of $411 \pm 19 \mathrm{~kg}$ were evaluated. Every feedlot pen included three Aberdeen Angus and one Angus $\mathrm{x}$ Hereford crossbred steer.

Trial 2. Thirty-two Bos taurus (17Angus and eight Hereford) or Bos taurus crossbred (seven Angus $\mathrm{x}$ Hereford) steers, at the age of 24 months and $457 \pm 11 \mathrm{~kg}$ of weight were considered in a 71-d growthperformance Trial started in January 3rd, 2018. One Hereford, two Angus and one crossbred or Angus steer constitutes each pen.

Trial 3. Thirty-two steers Angus crosses, aged, approximately, 24 months and weighing $509 \pm 31 \mathrm{~kg}$ were evaluated from January 17th to April 2nd, 2019 (76-d on fed).

In the three trials, steers had access to fresh water ad libitum.

\section{Experimental measures and sample analyses On the commercial feedlot}

Weather and environmental measures. An automated weather station (Vantage Due, Davis Instruments, Hayward, CA), located $1.2 \mathrm{~km}$ away from the pens, recorded data at 30-min intervals. The following climatic variables were obtained: minimum and maximum air temperature, wind speed and direction, relative humidity, and precipitation. These data were used to calculate the daily mean and hourly THI according to the equation (Thom, 1959):

$$
T H I=0.8 \times T a+R H(T a-14.4)+46.4
$$

Where, $\mathrm{Ta}=$ ambient temperature in ${ }^{\circ} \mathrm{C}$ and $\mathrm{RH}=$ relative humidity in decimal form .

The combined intensity of temperature and humidity was classified into four THI values: normal (THI $\leq$ 74), alert $(74<\mathrm{THI}<79)$, danger (79 $\leq \mathrm{THI}<84)$, and emergency (THI $\geq 84)$ ( $\mathrm{LWSI}$ LCl, 1970). Based on THI value, we measured i. the night-time recovery period, i.e., the total number of hours with THI values below a base of 74 from 10:00 pm to 6:00 am (Hahn and Mader, 1997; Hubbard et al., 1999; Koknaroglu et al., 2008); and ii. the presence of a heat wave, i.e., a period of abnormally uncomfortable hot and usually humid weather of at least three successive days with maximum THI above a specific threshold, such as 72 (AMS, 1989; St. Pierre et al., 2003; Nienaber et al., 2007).

Development and growth. Before start and at the end of each trial, rib eye area $\left(\mathrm{cm}^{2}\right)$, subcutaneous fat thickness $(\mathrm{mm})$, rump fat $(\mathrm{mm})$, and intramuscular fat $(\%)$ were individually measured with an ALOKA® SSD 500(Hitachi Medical Corporation, Twinsburg, OH, USA), lineal prob ultrasound, with a $3.5 \mathrm{MHz}$.

Weights were recorded on individual unfasted steers at the beginning of the adaptation period, on the day 0 (initial weight; $\mathrm{kg}$ ), and then every 14 days before the first meal, and the average daily gain (ADG; $\mathrm{kg} / \mathrm{d}$ ) was calculated. On the dav before slauahter. steers were individually weighed (final weight; $\mathrm{kg}$ ), and then Loading [MathJax]/jax/output/CommonHTML/fonts/TeX/fontdata.js 
transported to a commercial abattoir. Feed intake per pen (experimental unit) was measured daily, from the difference between offered and refused, and dry matter was determined daily to calculate dry matter intake (DMl; kg DM/day). The individual ADG and DMI per pen were used to calculate feed efficiency (feed:gain ratio).

Behaviour. Animal behaviour was registered once (Trial 3) or twice (Trial 1 and 2) a month, during light hours - approximately, from 6:00 am to 7:30 pm. The time spent as inactive, in feeding, drinking, ruminating, and using the shade were recorded with instantaneous scan-sampling of steers and performed at 15-minutes interval (Mitlöhner et al., 2001b). Inactive behaviour included both standing (an upright posture, no locomotion) and lying (body contact with the ground). Feeding and drinking were defined as the head over the feed bunk or water trough, respectively. Rumination was considered as chewing regurgitated boluses of feed. A secondary behaviour, the use of shade, which could be performed at the same time as one of the primary behaviours, was also considered. Behaviours were summarized in minutes for each animal and then to each pen. To estimate the time animals under each treatment allocated to each activity, we assumed that the behaviour evaluated in the scan sample was the behaviour performed on the following 15 minutes. There were two-trained persons, in each trial, measuring behaviour. In Trial 1, these data were recorded in a subset of two steers/pen (on d 13, 27, 41, and 55; with 100 to 112 observations/pen/day); all steers were evaluated in Trial 2 (on d 22, 36, 50, and 64; with 232 to 240 observations/pen/day) and Trial 3 (on d 8, 35, and 63; with 208 to 224 observations/pen/day).

Respiration rate (RR) and panting score (PS). Individual data were obtained by two trained observers, in each studied trial, standing in front of each pen, at 7:00 am, 10:00 am, 3:00 pm, and 6:00 pm, twice weekly. The RR was determined by $30 \mathrm{~s}$ and the count was converted to breath per minute (bpm). The PS, an indication of heat stress in cattle, was determined based on visual observation of steers using the scoring system proposed by Gaughan et al. (2008) (from $0=$ no panting, animal under no heat load to 4.5 $=$ catastrophic stress, severely heat-stressed animal). A total of 17,19 , and 22 days of observation was considered for Trial 1, 2, and 3, respectively.

Rumen pH and temperature. On the last 28 (2017) and 47 (2018) days of the experiment, ruminal boluses (eBolus ${ }^{\circledR} ;$ eCow, United Kingdom) were placed in two (Trial 1) and one (Trial 2) steers/pen, which recorded $\mathrm{pH}$ and temperature each hour. A total of 15 boluses have been recovered directly from the rumen at slaughter, seven for no shade (four and three in Trial 1 and 2, respectively) and eight for shade access (five and three in Trial 1 and 2, respectively) treatments.

\section{On the abattoir}

Before slaughter, at the abattoir, the steers of each pen were collectively weighed and an average weight per animal was calculated (SW, slaughter weight; $\mathrm{kg}$ ). The hot carcass weight after dressing ( $\mathrm{HCW} ; \mathrm{kg}$ ) was obtained. The overall yield of the slaughter procedure $(\mathrm{Y} ; \%)$ was estimated as the ratio of $\mathrm{HCW}$ and SW.

Loading [MathJax]/jax/output/CommonHTML/fonts/TeX/fontdata.js jal analyses

Page $7 / 26$ 
In the Trial 3, six steers were eliminated due to injuries not direct related to treatment. One animal was excluded after 11 days due to illness; another developed a locomotor problem and was excluded on day 22 ; and on day 70 , all the four steers from one shade pen were excluded due to locomotor and digestive problems.

This study consisted of three studied trial (blocks); each had two treatments. The experimental unit was the pen. The experimental design was a randomized complete block design. A total of twelve replications (pens; 4 pens/treatment/trial) were considered per treatment. All statistical analyses were performed using statistical package SAS 9.4 (SAS Institute Inc., Cary, NC, USA).

Average daily gain was calculated by slopes using linear regression. Performance, behavioural, and carcass data were analysed as a mixed linear model using the MIXED procedure. An ANOVA was performed with trial as a block and random effect and treatment as fixed effect. Initial weight was included as covariate in the model.

Physiological data were analysed as repeated measures using the PROC MIXED model procedure. The selection of covariance structure is according to the smallest value for Akaike's information criterion. For respiration rate and panting score, we used the heterogeneous auto regressive structure of first order (AR (1)). For ruminal temperature, the covariance structure used was the Banded Topelitz (TOEP) and for ruminal $\mathrm{pH}$, auto regressive structure of first order (AR (1)).

Treatments means of each variable were estimated using LSMEANS statement and compared using Tukey test. Statistical differences were determined by $\mathrm{P} \leq 0.05$ and tendency were declared when $0.05<$ $P \leq 0.10$. The physiological, behavioural, and performance data are expressed as mean \pm se.

Linear regressions were generated using PROC MIXED with respiration rate and panting score as the response variable; THI, treatment, moment of the day, trial and day as fixed effects; and pen as random effect.

\section{Results}

\section{Weather and environmental measures}

Weather data for the three trials are shown in Table 2 and in Supplementary Information. The THI averaged 71 and ranged from a daily average of 59 to 82 . Mean daily ambient temperature for the entire study was $24^{\circ} \mathrm{C}$ with an average daily low and high of 15 and $31^{\circ} \mathrm{C}$, respectively. Daily relative humidity air ranged from 15 to $99 \%$, with a mean of $72 \%$. Patterns of hourly climatic measures were similar between three trials, with an increase in temperature and THI index, and decrease in humidity relative, from 7:00 am to $15: 00 \mathrm{pm}$. 
Table 2

Average climatic measures and temperature-humidity index (THI value and category) summarized for each evaluated year

\section{Trial 1}

Trial 2

Trial 3

Daily ambient temperature, ${ }^{\circ} \mathrm{C}$

$\begin{array}{llll}\text { Average } & 23 & 25 & 23 \\ \text { Min. } & 17 & 19 & 15 \\ \text { Max. } & 30 & 31 & 30\end{array}$

Daily humidity relative, $\%$

$\begin{array}{llll}\text { Average } & 78 & 61 & 77 \\ \text { Min. } & 63 & 46 & 59 \\ \text { Max. } & 97 & 89 & 94\end{array}$

Daily THI

$\begin{array}{llll}\text { Average } & 71 & 72 & 70 \\ \text { Min. } & 61 & 63 & 59 \\ \text { Max. } & 81 & 78 & 82\end{array}$

THI category, days (\%)

$\begin{array}{llll}\text { Normal } & 49(74 \%) & 38(54 \%) & 54(71 \%) \\ \text { Alert } & 13(20 \%) & 33(46 \%) & 17(22 \%) \\ \text { Danger } & 4(6 \%) & 0 & 5(7 \%) \\ \text { Emergency } & 0 & 0 & 0\end{array}$

THI category: normal $(\mathrm{THI} \leq 74)$, alert $(74<\mathrm{THI}<79)$, danger $(79 \leq \mathrm{THI}<84)$, and emergency $(\mathrm{THI} \geq$ 84).

In accordance with average THI index of each trial, none of the years exposed the steers to some level of severe heat stress (i.e., alert, danger, and emergency categories). There were no days in "emergency" condition, and the total number of hours with THI $\geq 84$ occurred in $43(3 \%), 8(0.5 \%)$, and $53(3 \%)$ for Trial 1,2 , and 3 , respectively.

There were three major heat wave events of 12 (Trial 2), 13 (Trial 3), and 17 (Trial 1) days of duration. There were eight heat waves with short duration (three to eight days). One of these was in Trial 1, five in Trial 2, and two in Trial 3. During the three trials, 61 (94\%; Trial 1), 68 (96\%; Trial 2), and 63 (83\%; Trial 3) days (not consecutive) presented night-time recovery with more than $8 \mathrm{~h}$ with $\mathrm{THI} \leq 74$. 


\section{Development, growth, and carcass traits}

For ultrasonography measures, differences were observed only in subcutaneous fat thickness and rump fat measured before starting the study. The first measurement tended to be higher $(7.08 \pm 1.63 \mathrm{~mm} \mathrm{vs}$. $6.09 \pm 1.64 \mathrm{~mm} ; \mathrm{P}=0.08)$ and the second was significantly higher $(7.98 \pm 1.93 \mathrm{~mm} v \mathrm{~s} .6 .62 \pm 1.93 \mathrm{~mm} ; \mathrm{P}$ $=0.002)$ in no shaded compared to shaded steers.

The influence of shade on growth-performance steers is shown in Table 3. Initial body weight averaged $461 \mathrm{~kg}$ for shaded and no shaded animals. Shaded animals reached a final live weight that was $12 \mathrm{~kg}$ heavier $(P=0.04)$ than no shaded steers. Provision of shade enhanced ADG (13\%; $P=0.004)$, daily DMI $(6 \% ; P=0.003)$, and feed:gain ratio $(6 \% ; P=0.05)$. The slaughter weight of shaded steers was $10 \mathrm{~kg}$ greater $(P=0.02)$ than that of no shaded steers. There was a trend $(P=0.06)$ to higher carcass weight in steers from shade treatment, without treatment effect on carcass yield.

Table 3

Shade effect on the performance of feedlot cattle (mean \pm SE)

\begin{tabular}{|llll|}
\hline & Shade & No-shade & $P$ value \\
\hline Initial weight (kg) & $461 \pm 28$ & $461 \pm 28$ & 0.94 \\
\hline Final weight (kg) & $542 \pm 10$ & $530 \pm 10$ & 0.04 \\
\hline ADG (kg/day) & $1.32 \pm 0.08$ & $1.16 \pm 0.08$ & 0.004 \\
\hline DM (kg DM/day) & $10.8 \pm 0.3$ & $10.2 \pm 0.3$ & 0.003 \\
\hline Feed:Gain ratio (kg DM/kg BW) & $8.2 \pm 0.2$ & $8.8 \pm 0.2$ & 0.05 \\
\hline Slaughter weight (kg) & $504 \pm 2$ & $494 \pm 2$ & 0.02 \\
\hline Carcass weight (kg) & $287 \pm 5$ & $282 \pm 5$ & 0.06 \\
\hline Carcass yield (\%) & $56.9 \pm 0.7$ & $57.0 \pm 0.7$ & 0.73 \\
\hline ADG: average daily gain; DM: dry matter & & \\
\hline
\end{tabular}

Access to shade increased the time animals spent feeding by $20 \%(P=0.008)$ and ruminating by $22 \%(P$ $=0.001)$ and decreased inactive behaviour by $7 \%(P<0.0001)($ Fig. 1$)$. The time spent drinking was numerically higher for no shaded than for shaded steers $(12 \pm 6 \mathrm{~min} /$ day $v s .8 \pm 6 \mathrm{~min} /$ day; $P=0.25)$. Steers in shaded treatment spent $320 \pm 33 \mathrm{~min} /$ day under shade.

Mitigation strategy had significant effect on diminish both respiration rate and painting score during the day, except early in the morning (Fig. 2). Regression analysis indicated that for each unit of increase in THI index, RR and PS increased by 56\% (1.37 \pm 0.06 bpm vs. $0.77 \pm 0.06$ bpm; $P<0.0001)$ and $33 \%(0.03$

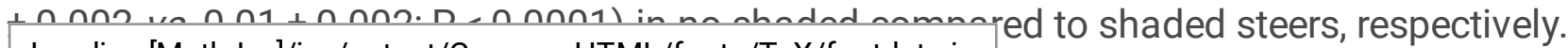


During the experiment, steers with access to shade, in comparison to no shade treatment, had a marked increase in ruminal $\mathrm{pH}(6.11 \pm 0.07$ vs. $5.99 \pm 0.07$, respectively; $\mathrm{P}<0.0001)$, without difference in ruminal temperature $(39.0 \pm 0.32 v s .39 .2 \pm 0.31$, respectively; $P=0.27)$. Throughout the day, both indicators of rumen were consistently higher for shade than for no shade treatments. For temperature, significant differences were observed in the early morning, while for $\mathrm{pH}$, differences were present in almost all day (Fig. 3).

\section{Discussion}

As we hypothesized, access to shade improved performance and carcass weight, and enhanced the behaviour and physiology, of steers during the fattening phase under feedlot conditions in the hottest months in Uruguay, despite the average THI was between 70 and 72. Climatic conditions, feed regime, and animal factors, as the ones took place on this study, might lead to an increase in body heat content beyond the animal's normal physiology, which would reduce its ability to cope with thermal stress (Gaughan et al., 2008), since we observed a positive response to shade access. Cattle have great susceptibility to heat stress due to their high metabolic rate and the poorly developed water retention mechanism in the kidney and guts (Bernabucci et al., 2010). Besides, there is notable difference in cattle breeds in their ability to regulate body temperature (Silanikove, 2000). Bos taurus cattle, the genotype used in this study, is particularly vulnerable to heat stress (Gaughan et al., 2008; Gaughan et al., 2010; Lees et al., 2019), attributable to physiological differences including metabolic rate, surface area and mass ratio, and hair coat (Brown-Brandl, 2008). Furthermore, cattle finished on feedlot conditions during the summer are even more susceptible to heat stress than in other feed regimes (Hubbard et al., 1999; Mitlöhner et al., 2002).

Lowering the temperature of the surroundings will reduce the radiation load on the animal or will increase its radiation loss (Bond et al., 1958). Solid shade - as used in all the three trials - can block almost $100 \%$ of the direct rays of the sun (Brown-Brandl et al., 2013). According to Mader et al. (1999a), the black globe temperature under shade, which was obtained $2.1 \mathrm{~m}$ above ground level, averaged $2^{\circ} \mathrm{C}$ less than that without shade, reaching a peak difference of $8^{\circ} \mathrm{C}$ at 3:00 pm. Based on our results, and on researches conducted with heifers (Mitlöhner et al., 2001a; Mitlöhner et al., 2002), bulls and steers (Blaine and Nsahlai, 2011) or steers (Koknaroglu et al., 2008); in commercial (Brown-Brandl et al., 2005) or experimental feedlots (Hagenmaier et al., 2016); and with different cattle genotypes (Gaughan et al., 2010; Brown-Brandl et al., 2013), shade protects from the sun and reduces the radiation load, improving both welfare and production of cattle during summer.

\section{Climatic measures}

Summers in Uruguay are generally characterized by hot daytime temperatures and relatively cool temperatures at night. Climatic conditions during the trials were generally typical for the area and the patterns of temperature, humidity air, and THI were similar in the three evaluated years. Although THI has 
generally considered as the most reliable indicator for animals and becomes the method of choice in near all countries (Silanikove, 2000; Sejian et al., 2018; Lacetera, 2019). The summer on 2017 (Trial 2) was different from the others - was relatively dry and cool, with 674 experimental hours (40\%) or 33 days (46\%) reaching $\mathrm{THI} \geq 74$, with no hour and or day detected as "danger" or "emergency" situation. A THI < 74 generally does not cause safety problems in healthy animals (Hubbard et al., 1999); however, a THI between 70 and 74, like in our study, could be an indicator or alert for cattle feeders to be aware for a potential thermal stress in cattle (Mader et al., 2006), especially in those under high metabolic rate as the ones in feedlot conditions (Blaine and Nsahlai, 2011).

As has been highlighted by Hahn and Mader (1997), a heat wave is an event that strongly impacts on cattle physiology and performance, and the most devastating ones generally occurred in early summer before animals were acclimatized to high temperature (Nienaber and Hahn, 2007). In the current study, heat waves were observed to occur between mid-January to mid-February and from the total of 11 , four of these were separated by only one (Trial 2) or two (Trial 1) days. Despite the steers were near to market weight with high condition score, factors that may difficult transferring heat to the surface of the skin by evaporation (Brown-Brandl, 2008), none of the eliminated steers were direct result from this phenomenon. Even though heavy cattle have difficult to cool themselves (Grandin, 2016), they also have a capacity to cope with many acute and moderate thermal challenges through acclimation or acclimatization, with the goal of maintaining the well-being (Nienaber and Hahn, 2007; Bernabucci et al., 2010). Nevertheless, in the last Trial, we observed digestive and locomotor problems that could be secondary to heat stress. As mentioned by Hahn (1999), a combination of increases in the potential metabolic heat production with the environmental heat load of the second heat wave, may exceed the capacity of vulnerable animals to dissipate heat and predispose them to acidosis.

We observed more than $80 \%$ of the night-time with $\mathrm{THI}<74$, that would allow steers radiate, whereas at normal temperatures there will be little heat gain or loss from conduction or convection. Moreover, during cooler nights, cattle may increase RR to enhance heat dissipation (Gaughan et al., 2000). The severity of heat stress depends to a large extent on the diurnal fluctuations of the ambient temperature (Silanikove, 2000); our data showed an average diurnal variation on temperature from 12 to $13^{\circ} \mathrm{C}$, which is considered intermediate. Furthermore, based on tympanic temperature, cattle that fail to or do not cool down at night are more prone to achieve high temperatures during hot days (Mader et al., 2010).

\section{Development, growth, ruminal $\mathrm{pH}$ and temperature, and carcass traits}

Although a stress threshold temperature of $25^{\circ} \mathrm{C}$ coincides with feed intake reduction (Hahn, 1999), our results showed negative effect in animal performance under a mean daily ambient temperature of $24^{\circ} \mathrm{C}$. Consistent with previous experiments (Mitlöhner et al., 2001a; Mitlöhner et al., 2002; Barajas et al., 2013), provision of shade to the steers in our study enhanced ADG, DMI, gain efficiency, and rumen physiology over that of no shaded steers. Heat stress provokes a reduction in feed intake, increase maintenance 
boosted by the expenditure of energy ride to the body form heat load excess by increasing in respiration rate and other related activities (Fuquay, 1981). Hyperventilation, in combination with reduced fibre intake, slug feeding and decreased salivary buffering caused by excessive drooling may also reduce $\mathrm{pH}$ of rumen (Bernabucci, 2010; van Laer et al., 2014), as in our study in no shade steers. These benefits might be applied only to the finishing stages of growth, when feedlot cattle deposit more fat tissue than in other development phases, increasing the vulnerability of the animal (Brown-Brandl, 2008; Blaine and Nsahlai, 2011).

The appetite of cattle is often suppressed when they are exposed to heat environment (Blackshaw and Blackshaw, 1994; Hahn, 1999; Mader et al., 2007) and the most important factors explaining this variation are the average and the daytime temperature (Koknaroglu et al., 2008). Our results are in line with these authors and with results from other researches, which also observed that cattle in outside lots with overhead shelter were heavier and had higher DMI than those with no access to overhead shelter, due to protection of the solar radiation and to be able to lie down during nigh-time and dissipate the heat produced during the day (Mitlöhner et al., 2001a; Mitlöhner et al., 2002; Koknaroglu et al., 2008). In study done with Angus cattle, those with access to shade had $4.7 \%$ mean reduction in feed intake compared to the same cattle breed managed in un-shaded pens, which had a decreased of $14.3-15.8 \%$, when exposed to a hot stress situation (Gaughan et al., 2010). Animals under heat environment lose body weight and/or mobilize adipose tissue due to a combination of reduction in feed intake and increases in energy expenditure for maintenance (Lacetera, 2019). According to Barajas et al. (2013), the improvements in apparent energetic efficiency may be related, in part, to a reduction in the maintenance energy requirements and a more efficient intestinal nutrient uptake. Obviously, a voluntary reduction in feed intake is not beneficial either to animal performance or to well-being; however, contributes to the maintenance of core body temperature, as a part of acclimation and adaptation to hot environments (Lees et al., 2019).

It has been reported in finishing beef cattle, when stressful thermal conditions last for relative short period and are followed by enough time for the animals to recover, a possibility to take place compensatory gain (Summer et al., 2019), whenever the performance penalties are slight to moderate (Nienaber and Hahn, 2007). Although a compensation through reduce feed:gain ratio by cattle with provided no shade in last $57 \mathrm{~d}$ to finish was evidenced by Mader et al. (1999a), we did not observe compensatory gains by no shaded steers (12 kg lighter than shaded steers). Clearly, although the weather condition during the three years was sufficient to lower performance (Tables 2 and 3 ), the steers also could have compensated over the 70-d trial.

Nevertheless, other researchers have speculated that shelter or shade use, in general, do not benefit cattle performance (Koknaroglu et al., 2008; Mader et al., 2010; Blaine and Nsahlai, 2011). Furthermore, feed intake has been classified as a non-reliable parameter (Gaughan et al., 2008), since it has an intermittent pattern and delayed response as the animals adjust their feed intake based on many factors, in addition to current temperature (Brown-Brandl et al., 2005). Regardless of access or not access shade, peaks of 
day of the event, but rather on the subsequent day due to carry-over heat loads (Hagenmaier et al., 2016). As showed by Koknaroglu et al. (2008), the ability of cattle to dissipate heat during the night, where the temperature is coolest, might influence on the next day's performance. The acute response to hot conditions requires, approximately, three days for the cattle to regain a balance between the metabolic heat production and the ability to dissipate; and about 7-8 days to enter in a chronic stage heat, measure by tympanic temperature (Hahn and Nienaber, 1993), which is driven by continued exposure of the animal to the stressor (Collier et al., 2019). Brown-Brandl et al. (2003) related a decrease throughout the day of heat production to the feeding behaviour and an acclimation to the elevated temperatures on about day seven of high temperatures.

Digestion and absorption processes carried out by the animals are affected by the thermal environment (Lees et al., 2019). Rumen measurements, and boluses are ideal for adaptation studies, is a newest and useful technique to assess variation responses of cattle exposed to heat load, as can give continuous data and in real time (Sejian et al., 2018). As expected, ruminal pH and temperature increased in steers from shade access treatment. Berbabucci et al. (2010) and Lacetera (2019) reported a lower feed intake and rumination in heat-stressed steers, which decrease buffering agents entering the rumen, consequently, concentration of volatile fatty acids increases, since they are less absorbed, decreasing ruminal $\mathrm{pH}$.

In the current study, shaded cattle had greater final and slaughter weight, which agrees with previous feedlot studies conducted with heifers in Texas (Mitlöhner et al., 2001a; Mitlöhner et al., 2002), with bulls and steers in South Africa (Blaine and Nsahlai, 2011), and with steers in California (Barajas et al., 2009; 2013). No shaded animals required 4.1 (steers) to 21 (heifers) additional days to achieve the equivalent final live weight of the shaded ones, increasing the cost of production (Mitlöhner et al., 2001a; Blaine and Nsahlai, 2011). We observed that a higher SW for shaded steers translated to a tendency to higher hot carcass weight as well. In agreement, Mitlöhner et al. (2002) reported a $7.3 \mathrm{~kg}$ in HCW of shaded heifers, $2 \mathrm{~kg}$ higher than we observed in the steers of the current study.

\section{Respiration rate, painting score, and behaviour}

Ruminants have mainly diurnal habits, being active during the day and inactive at night (Silanikove, 2000). However, under experimental feedlot conditions, with no environmental enrichments, behaviours are limited to maintenance behaviours, such as feeding, drinking, walking, standing, and lying (Mitlöhner et al., 2001a). Behavioural adaptation is recognized as the first and foremost important adopted by animals to reduce heat load (Gaughan et al., 2008; Sejian et al., 2018; Summer et al., 2019).

Behavioural measurements were limited to three (Trial 3) and four (Trial 1 and 2) days; however, the present data should reflect the patterns of behaviour developed over time in the two treatment groups. Our results showed a marked effect of shade on feeding, ruminating, and inactive time, which agrees with previous studies conducted with crossbred steers in South Africa (Blaine and Nsahlai, 2011) and with Angus and Charolais-crossbred' heifers in USA (Mitlöhner et al., 2002). 
Heat production has been shown to be closely associated with feeding time (Brown-Brandl et al., 2003). Relative to steers with access to shade, no shaded ones responded to high ambient temperatures by spending 15 and $27 \mathrm{~min} /$ day less in feeding and in ruminating activities, respectively. In agreement with Lees et al. (2020), steers of shade treatment showed higher DMI, which determined more time performing ingestive behaviour that those in no-shade treatment. Feeding can help to reduce heat dissipate, because respiration rate, i.e., evaporative loss from the lung surface, reduces during this behaviour (Blaine and Nsahlai, 2011). Heat-stressed cattle consume smaller meals, more frequently, and shifting feed intake to cooler parts of the day (Brown-Brandl et al., 2003; Bernabucci et al., 2010; Lacetera, 2019), except in the "emergency" category, which cattle cannot shift (Brown-Brandl et al., 2005). Blaine and Nsahlai (2011) demonstrated a peak feeding period at 2:00 pm to shaded cattle as opposed to 4:00 pm to no shaded ones, demonstrating that the shade reduces the impact of midday temperature highs and encouraged feed activity. Also, the observations of rumination are related to the amount of feed consumed rather than exposures to heat load per se (Lees et al., 2020).

Results of the time in inactive behaviour, which was higher in no shaded steers, included two postures behaviours, standing, and lying down. Steers without access to shade consumed less feed, consequently, ruminated less, and resulted also more inactive, leading to production losses (Summer et al., 2019). When ground temperature exceeds skin temperature, as probably occurred in no shaded treatment in the current study, heat will flow from the ground to the steer, increasing the heat load to be dissipated. Generally, heat stressed animals tend to increase connective heat loss from the surface of the body and to avoid additional heat gain by conduction from the ground (Morrison, 1983; Sejian et al., 2018). The lying down position allows the animals reorient themselves in different directions, avoiding direct solar radiation, as well as ground radiation obstruct the conductive heat transfer into the animal body and facilitate the dissipation of the body heat load to the surroundings (Gaughan et al., 2002; Brown-Brandl, 2008; Sejian et al., 2018). On the other hand, Mitlöhner et al. (2002) observed, in commercial feedlots, an increment in standing behaviour in heat-stressed heifers in the hottest hours of the day. Altogether, the observation of inactive behaviour in our study was not suitable to conclude that shade improved the time of steers lying down, i.e., thermal comfort, or standing posture.

Water intake requirements are increased in heat-stressed cattle to accommodate increased evaporative heat loss requirements (Mitlöhner et al., 2001a; Brown-Brandl, 2008; Arias and Mader, 2011; Collier et al., 2019). In agreement with previous studies (Mitlöhner et al., 2001a; Barajas et al., 2013), we did not observe a significant effect of shade on drinking time, despite the no shaded steers spent more minutes drinking than shaded ones. Castañeda et al. (2004) commented that in areas without shade, the cattle seek water to reduce their body heat by drinking, splashing, breathing over the cooler surface of the water, or getting some shade over their heads. In the present study, water troughs were located within an unshaded region, and then the water was probably not cool during the day. Under severe condition, cold water can improve rate gain (Bond et al., 1958; Brown-Brandl, 2008) and diminish quantity of water required for cooling beef cattle (Blackshaw and Blackshaw, 1994; Mader, 2014). Maximizing water intake facilitates heat loss through increased water turnover (Fuquay, 1981) by evaporative cooling (Morrison, Loading [MathJax]/jax/output/CommonHTML/fonts/TeX/fontdata.js est predictors of affecting daily water intake are 
$\mathrm{TH}$, following by ambient and minimum temperature, with solar radiation and dry matter intake having a smaller effect.

One of the fastest and most profound behavioural changes in heat stressed animals is the seeking for shade, due to lower radiant heat and lower ground temperature (Mitlöhner et al., 2002; Sejian et al., 2018). In our study, steers stayed under the shade nearly to a quarter of the day. As mentioned by Blaine and Nsahlai (2011), the number of animals found under the shade reduces with increasing in relative humidity, since high humidity can be associated to low temperatures because of rain. In the South-east of Queensland, Australia, where the climate is subtropical with hot and humid summer, like in Uruguay, Angus steers exhibited the greatest use of shade from 8:00 am to 4:00 pm (Lees et al., 2020), possibly due to the highest radiation load during this period. Caution is need, since the prolonged time that the steers spend under the shade led to increase soil moisture because of urination and defecation in this area (Mitlöhner et al., 2002).

Under thermal stress, evaporative loss is the only means by which an animal can dissipate heat, either by panting or sweating, to lose excessive body heat (Blackshaw and Blackshaw, 1994; Davis et al., 2003; Mader, 2003). As body temperature is difficult to assess under field condition, a logical choice for physiological indicators is the respiration rate and panting, since it is easy and cheap to monitor, providing to producer the animal's thermal status (Silanikove, 2000). Moreover, a strong correlation between body temperature, respiration rate and panting was observed by Gaughan and Mader (2014). The RR lags ambient temperature by 1 to $2 \mathrm{~h}$ (Hahn and Mader, 1997; Gaughan et al., 2000; Brown-Brandl et al., 2003; Brown-Brandl et al., 2005) and the painting score, by 2-h (Mader et al., 2006). Cattle under average condition, the RR should be lower than $60 \mathrm{bpm}$ (Hahn, 1999; Silanikove, 2000), with significant rise in environmental temperature (from 18 to $34^{\circ} \mathrm{C}$ ) may double the normal value (from 55 to $103 \mathrm{bpm}$ ) (Brown-Brandl et al., 2003). A threshold of approximately $21^{\circ} \mathrm{C}$ was identified to increase RR (Hahn, 1999), and an increase in breaths rate above $40 \mathrm{bpm}$ may be regarded as panting to increase evaporation and body cooling (Silanikove, 2000).

In general, our data showed values for RR greater than the reference values and, as expected, respiratory rate increased with panting progressing to open-mouth breathing, when steers were exposed to increment in environmental heat (Sejian et al., 2018; Lacetera, 2019). Based on regression analysis, a change of one unit of THI corresponded to higher increase in RR (1.37 and $0.77 \mathrm{bpm})$ and PS (0.03 and 0.01) in no shaded compared to shaded steers, respectively. A relation between RR and PS has been previously documented in the literature: an initial open mouth is observed with a minimal bpm of 70 , indicating fast painting (Gaughan et al., 2002). Increased water loss via skin and respiratory evaporation can disturb body water levels and mineral concentration (Bernabucci et al., 2010), increasing the incidence of respiratory alkalosis and ruminal acidosis (Lees et al., 2019), impairing the animal's ability to cope with heat load conditions. Respiration rate is impacted by the time of the day (am or pm), THI category, shade access, and breed/coat colour (Aberdeen Angus > Charolais) (Brown-Brandl et al., 2013). Days with THI $\geq$ 79 , classified as "danger", increases open mouth breathing compared to $74 \leq \mathrm{THI}<79$, classified as

Loading [MathJax]/jax/output/CommonHTML/fonts/TeX/fontdata.js et al., 2016).

Page 16/26 
We observed that both physiological indicators, RR and PS, were affected by time of the day. Only in the early morning we did not detect significant differences between treatments, which could be explained by the lower ambient heat load at this time of the day relative to midday and afternoon as suggested by Gaughan and Mader (2014). The largest differences between treatments were observed at 10:00 am and at 3:00 pm: RR ranged from $11 \mathrm{bpm}$ to $13 \mathrm{bpm}$ and PS, from 0.2 to 0.4 . Lees et al. (2020) reported that shaded cattle may have diverted a greater quantity of energy toward to maintain homeostasis, supported by lower RR and PS, i.e., a reduced accumulated heat load status, as opposed to unshaded steers. A dynamic response for RR was mentioned by Brown-Brandl et al. (2005), who showed that cattle in the shade treatment had slower increase in mean daily RR with the THI increases than cattle without access to shade. A threshold of $25^{\circ} \mathrm{C}$ black global temperature is determined for increase RR (Gaughan et al., 2008) and, under heat conditions, the increase in RR varies from 2.8 to $3.3 \mathrm{bpm}$ for each $1^{\circ} \mathrm{C}$ increment in ambient temperature. According to Eigenberg et al. (2005), the effect of shade is evident from about 10:00 am to 7:00 pm, with differences rate of increase in the daytime $\left(5.4 \mathrm{bpm}\right.$ each $1^{\circ} \mathrm{C}$ increment in ambient temperature) and night-time ( $4.5 \mathrm{bpm}$ each $1^{\circ} \mathrm{C}$ ambient increment).

Access to shade is a valuable technique to minimize heat stress in feedlot British steers' and enhanced production and welfare during hottest months in Uruguay, even with an average $\mathrm{THI}$ ranging from 70 and 72. However, mitigation opportunities need to be evaluated for individual livestock systems and choosing a single management strategy for an entire feedlot could be considered cost-prohibitive (Brown-Brandl et al., 2013). Even it is being of knowledge the negative effects of heat stress on animal health and welfare (Lacetera, 2019), like subclinical acidosis, lameness, and deaths in Uruguay (Banchero et al., 2016), nowadays, the decision to do this investment is more dependent by the direct economic losses, like daily growth rate and cattle deaths (Hagenmaier et al., 2016).

Under Uruguayan summertime heat, in allocation with an average THI from 70 to 72 , providing 4.5 $\mathrm{m}^{2} /$ steers of shade decreased respiration rate and panting score, suggesting that heat stress was visually alleviated. Additionally, animals increased time in feeding and ruminating, with an improved feed efficiency, the ultimate driver of feedlot performance. Cattle with access to shade were able to dissipate heat stored during the day at night and were able to alleviate the effect of heat load. Based on these results, shade would be expected to improve both performance and welfare in feedlot cattle fattening even in location with an average THI ranging between 70 and72.

\section{Declarations}

\section{Acknowledgments}

A special thanks to the management and staff of the feedlot who participated in the studies.

Funding. This project was funded by Instituto Nacional de Investigación Agropecuaria (INIA), Uruguay, and by MARFRIG Group. 
Conflict of interest. The authors declare no conflicts of interest.

Availability of data and material. The data sets analysed during the current study are available from the corresponding author upon reasonable request

Code availability. Not applicable.

Ethics approval. All procedures involving animal care and management were approved by the Committee for the Ethical Use of Animals of the National Institute of Agricultural Research (Protocol number 2016.53).

Consent to participate. All authors have consented to participate.

Consent to publish. All authors have approved to publish.

\section{References}

AMS, 1989. Glossary of Meteorology, fifth ed. Am. Meteorological Society, Boston, MA. http://glossary.ametsoc.org/wiki/Heat_wave. Accessed 2 Feb 2021.

AOAC International, 1990. Official Methods of Analysis, 15th ed, (AOAC Int., Arlington, VA).

Armstrong, D.V., 1994. Heat stress interaction with shade and cooling, Journal of Dairy Science 77, 20442050. https://doi.org/10.3168/jds.S0022-0302(94)77149-6.

Arias, R.S., Mader, T.L., 2011. Environmental factors affecting daily water intake on cattle finished in feedlots, Journal of Animal Science 98, 245-251. https://doi:10.2527/jas.2010-3014.

Banchero, G., Chalkling, D., Mederos, A., 2016. Relevamiento de problemas sanitarios y de manejo durante la terminación en bovinos en sistemas de confinamiento en Uruguay, Veterinaria (Montevideo) 52, 4-13.

Barajas, R., Cervantes, B.J., Espino, M.A., Juarez, F., Romo, J.A., Velasquez, E.A., 2009. Influence of penshade on feedlot performance and carcass characteristics of bulls naturally exposed long time to high temperature. Proceedings of the 61st Western Section American Society of Animal Science, Colorado, $2009,112-115$.

Barajas, R., Garces, P., Zinn, R., 2013. Interactions of shade and feeding management on feedlot performance of crossbred steers during seasonal periods of high ambient temperature, Professional Animal Scientist 29, 645-651. https://doi.org/10.15232/S1080-7446(15)30296-5.

Bernabucci, U., Lacetera, N.M, Baumgard, L.H., Rhoads, R.P., Ronchi, B., Nardone, A., 2010. Metabolic and hormonal acclimatation to heat stress in domesticated ruminants, Animal 4, 1167-1183. https://doi.org/10.1017/S175173111000090X. 
Blackshaw, J.K., Blackshaw, A.W., 1994. Heat stress in cattle and the effect of shade on production and behaviour: a review, Australian Journal of Experimental Agriculture,34, 285-295.

Blaine, K.L., Nsahlai, I.V., 2011. The effects of shade on performance, carcass classes, and behaviour of heat-stressed feedlot cattle at the finisher phase, Tropical Animal Health and Production 43, 609-615. https://doi: 10.1007/s11250-010-9740-x.

Bond, T.E., Kelly, C.F., Heitman Jr., H., 1958. Improving livestock environment in high temperature areas, The Journal of Heredity 49, 75-79. https://doi.org/10.1093/oxfordjournals.jhered.a106770.

Brown-Brandl, T.M., Nienaber, J.A, Eigenberg, R.A., Hahn, G.L., Freely, H., 2003. Thermoregulatory responses of feeder cattle, Journal of Thermal Biology 28, 149-157. https://doi.org/10.1016/S03064565(02)00052-9.

Brown-Brandl, T.M., Eigenberg, R.A., Nienaber, J.A, Hahn, G.L., 2005. Dynamic response indicators of heat stress in shaded and no shaded feedlot cattle, Part 1: analyses of indicators, Biosystems Engineering 90, 451-462. https://doi:10.1016/j.biosystemseng.2004.12.006.

Brown-Brandl, T.M., 2008. Heat stress in feedlot cattle, CAB Review: Perspectives in Agriculture, Veterinary Science, Nutrition and Natural Resources 3, 1-14. https://doi:10.1079/PAVSNNR20083016.

Brown-Brandl, T.M., Eigenberg, R.A., Nienaber, J.A. Benefits of providing shade to feedlot cattle of different breeds. Proceedings of the 2013 American Society of Agricultural and Biological Engineers, Missouri, 2013, 1563-1570. http://dx.doi.org/10.13031/trans.56.9902.

Busby, D., Loy, D., 1996. Heat stress in feedlot cattle: producer survey results, Beef Research Report, paper 26. http://lib.dr.iastate.edu/beefreports_1996/26. Accessed 17 Mar 2021.

Castañeda, C.A., Gaughan, J.B., Sakaguchi, Y., 2004. Relationships between climatic conditions and behaviour of feedlot cattle, Animal Production in Australia 25, 33-36.

Collier, R.J., Baumgard, L.H., Zimbelman, R.B., Xiao, Y., 2019. Heat stress: physiology of acclimatation and adaptation, Animal Frontiers 9, 12-19. https://doi:10.1093/af/vfy031.

Davis, M.S., Mader, T.L., Holt, S.M., Parkhurst, A.M., 2003. Strategies to reduce feedlot cattle heat stress: effects of tympanic temperature, Journal of Animal Science 81, 649-661.

https://doi:10.2527/2003.813649x.

Eigenberg, R.A., Brown-Brandl, T.M., Nienaber, J.A., Hahn, G.L., 2005. Dynamic response indicators of heat stress in shaded and no shaded feedlot cattle, Part 2: predictive relationships, Biosystems Engineering 91, 111-118. https://doi.org/10.1016/j.biosystemseng.2005.02.001.

Fuquay, J.W., 1981. Heat stress as it affects animal production, Journal of Animal Science 52, 164-174. 
Gaughan, J.B., Holt, S.M., Hahn, G.L., Mader, T.L., Eigenberg, R., 2000. Respiration rate - Is it a good measure of heat stress in cattle?, Asian-Australasian Journal of Animal Sciences 13(Supplement), C: 329332.

Gaughan, J.B., Mader, T.L., Holt, S.M., Hahn, G.L., Young, B.A., 2002. Review of current assessment of cattle and microclimate during periods of high heat load, Animal Production in Australia 24, 77-80.

Gaughan, J.B., Mader, T.L., Holt, S.M., Lisle, A., 2008. A new heat load index for feedlot cattle, Journal of Animal Science 86, 226-234. https://doi:10.2527/jas.2007-0305.

Gaughan, J.B., Mader, T.L., Holt, S.M., Sullivan, M.L., Hahn, G.L., 2010. Assessing the heat tolerance of 17 beef cattle genotypes, International Journal of Biometeorology 64, 617-627. https://doi:10.1007/s00484009-0233-4.

Gaughan, J.B., Mader, T.L., 2014. Body temperature and respiratory dynamics in un-shaded beef cattle, International Journal of Biometeorology 58, 1443-1450. https://doi.org/10.1007/s00484-013-0746-8.

Goering, H., Van Soest, P., 1970. Forage fiber analysis (apparatus, reagents, procedures and some applications). Agriculture handbook No. 379, (U.S. Agricultural Research Service, Washington DC).

Grandin, T., 2016. Evaluation of the welfare of cattle housed in outdoor feedlot pens, Veterinary and Animal Science 1, 23-28. https://doi.org/10.1016/j.vas.2016.11.001.

Hagenmaier, J.A., Reinhards, C.D., Bartle, S.J., Thomson, D.U., 2016. Effects of shade on animal welfare, growth performance, and carcass characteristics in large pens of beef cattle fed a beta agonist in a commercial feedlot, Journal of Animal Science 94, 5064-5076. https://doi:10.2527/jas.2016-0935.

Hahn, G.L., Bond, T.E., Kelly, C.F. Walls influence interior radiant environment of livestock shelters for shade, California Agriculture 17, 10-11. 1963.

Hahn, G.L., Nienaber, J.A. Characterizing stress in feeder cattle. U.S. Meat Animal Research Center. 120. 1993. https://digitalcommons.unl.edu/hruskareports/120. Accessed 15 Jan 2021.

Hahn, G.L., Mader, T.L. Heat waves in relation to thermoregulation, feeding behavior, and mortality of feeder cattle. Proceedings of the 5th International Livestock Environment Symposium Minneapolis, Michigan, 1997, 563-567.

Hahn, G.L., 1999. Dynamic response of cattle to thermal heat loads, Journal of Animal Science 77(suppl.2), 10-12. https://doi.org/10.2527/1997.77suppl_210x.

Harris, L., 1970. Compilación de datos analíticos y biológicos en la preparación de cuadros de composición de alimentos para uso en los trópicos de América Latina, (Department of Animal Science, Florida University, USA). 
Hubbard, K.G., Stooksburry, D.E., Hahn, G.L., Mader, T.L., 1999. A climatological perspective on feedlot cattle performance and mortality related to the temperature-humidity index, Journal of Production Agriculture 12, 650-653. https://doi.org/10.2134/jpa1999.0650.

Koknaroglu, H., Otles, Z., Mader, T., Hoffman, M.P., 2008. Environmental factors affecting feed intake of steers in different housing systems in the summer, International Journal of Biometeorology 51, 419-429. https://doi: 10.1007/s00484-007-0136-1.

Lacetera, N., 2019. Impact of climate change on animal health and welfare, Animal Frontiers 9, 26-31. https://doi.org/10.1093/af/vfy030.

LCl, 1970. Patterns of transit losses, (Livestock Conservation, Inc., Omaha, NE).

Lees, A.M., Sejian, V., Wallage, A.L., Steel, C.C., Mader, T.L., Lees, J.C., Gaughan, J.B., 2019. The impact of heat load on cattle, Animals 9, 322. https://doi: 10.3390/ani9060322.

Lees, A.M., Lees, J.C., Sejian, V., Sullivan, M.L., Gaughan, J.B., 2020. Influence of shade on panting score and behavioural responses of Bos taurus and Bos indicus feedlot cattle to heat load, Animal Production Science 60, 305-315. https://doi.org/10.1071/AN19013.

Mader, T.L., Dahlquist, J.M., Hahn, G.L., Gaughan, J.B., 1999a. Shade and wind barrier effects on summertime feedlot cattle performance, Journal of Animal Science 77, 2065-2072. https://doi.org/10.2527/1999.7782065x.

Mader, T.L., Hahn, G.L., Gaughan, J.B., Hu, Q.X., J.A. Heat waves and their impacts on feedlot cattle. Proceedings of the Biometeorology and Urban Climatology at the Turn of the Millennium, Sydney, 1999b, paper ICB 13.1.

Mader, T.L., 2003. Environmental stress in confined beef cattle, Journal of Animal Science 81(suppl. 2), E110-E119. https://doi.org/10.2527/2003.8114_suppl_2E110x.

Mader, T.L., Davis, M.S., Brown-Brandl, T.M., 2006. Environmental factors influencing heat stress in feedlot cattle, Journal of Animal Science 84, 712-719. https://doi:10.2527/2006.843712x.

Mader, T.L., Davis, M.S., Gaughan, J.B., 2007. Effect of sprinkling on feedlot microclimate and cattle behavior, International Journal of Biometeorology 5, 541-551. https://doi:10.1007/s00484-007-0093-8.

Mader, T.L., Gaughan, J.B., Johnson, L.J., Hahn, G.L., 2010. Tympanic temperature in confined beef cattle exposed to excessive heat load, International Journal of Biometeorology 59, 625-634. https://doi:10.1007/s00484-009-0229-0.

Mader, T.L., 2014. Animal welfare concerns of cattle exposed to adverse environmental conditions, Journal of Animal Science 92, 5316-5324. https://doi.org/10.2527/jas.2014-7950. 
MVOTMA/MGAP/INIA/AUPCIN, 2017. Guía de buenas prácticas ambientales y sanitarias de establecimientos de engorde de bovinos a corral. Montevideo, UY. https://www.mvotma.gub.uy/. Accessed 5 Jun 2021.

Mitlöhner, F.M., Morrow J.L., Dailey, J.W., Wilson, S.C., Galyean, M.L., Miller, M.F., McGlone, J. J., 2001a. Shade and water effects on behaviour, physiology, performance, and carcass traits of heat-stressed feedlot cattle, Journal of Animal Science 79, 2327-2335. https://doi:10.2527/2001.7992327x.

Mitlöhner, F.M., Morrow-Tesch, J.L., Wilson, S.C., Dailey, J.W., McGlone, J.J., 2001b. Behavioral sampling techniques for feedlot cattle, Journal of Animal Science 79, 1189-1193.

https://doi:10.2527/2001.7951189x.

Mitlöhner, F.M., Galyean, M.L., McGlone, J.J., 2002. Shade effects on performance, carcass traits, physiology, and behaviour of heat-stressed feedlot heifers, Journal of Animal Science 80, 2043-2050. https://doi.org/10.1093/ansci/80.8.2043.

Morrison, S.R., 1983. Ruminant heat stress: effect on production and means of alleviation, Journal of Animal Science 57, 1594-1600. https://doi.org/10.2527/jas1983.5761594x.

NASEM, 2016. Nutrient requirements of beef cattle, eighth revised ed., (National Academy Press, Washington, DC).

Nienaber, J.A., Hahn, G.L., 2007. Livestock production system management responses to thermal challenges, International Journal of Biometeorology 52, 149-157. https://doi:10.1007/s00484-007-0103-x.

Nienaber, J.A., Hahn, G.L., Brown-Brandl, T.A., Eigenberg, R.A. Summer heat waves - extreme years. Proceedings of the American Society of Agricultural and Biological Engineers, Minnesota, 2007, Paper $\mathrm{n}$. 074084. https://doi:10.13031/2013.23106.

Schutz, J.S., Wagner, J.J., Neuhold, K.L., Archibeque, S.L., Engle, T.E., 2011. Effect of feed bunk management on feedlot steer intake, The Professional Animal Scientist 27, 395-401. https://doi.org/10.15232/S1080-7446(15)30511-8.

Sejian, V., Bhatta, R., Gaughan, J.B., Dunshea, F.R., Lacetera, N., 2018. Review: adaptation of animals to heat stress, Animal 12(S2), s431-s444. https://doi.org/10.1017/S1751731118001945.

Schwartzkopf-Genswein, K.S., Beauchemin, K.A., Gibb, D.J., Crews, Jr., D.H., Hickman, D.D, Streeter, M., McAllister, T.A., 2003. Effect of bunk management on feeding behavior, ruminal acidosis and performance of feedlot cattle: a review, Journal of Animal Science 8(E-Suppl. 2), 149-158. https://doi.org/10.2527/2003.8114_suppl_2E149x.

Silanikove, S., 2000. Effects of heat stress on the welfare of extensively managed domestic ruminants, Livestock Production Science 67, 1-18. https://doi.org/10.1016/S0301-6226(00)00162-7. 
St-Pierre, S.T., Cobanov, B., Schnitkey, G., 2003. Economic losses from heat stress by US livestock industries, Journal of Dairy Science 86, E52-E77.https://doi.org/10.3168/jds.S0022-0302(03)74040-5.

Summer, A., Lora, I., Formaggioni, P. Gottardo, F., 2019. Impact of heat stress on milk and meat production, Animal Frontiers 9, 39-46. https://doi.org/10.1093/af/vfy026.

Thom, E.C. 1959. The discomfort index. Weatherwise, 12, 57-60.

https://doi.org/10.1080/00431672.1959.9926960.

van Laer, E., Moons, C.P.H., Sonck, B., Tuyttens, F.A.M., 2014. Importance of outdoor shelter for cattle in temperate climates, Livestock Science 159, 87-101. https://doi.org/10.1016/j.livsci.2013.11.003.

Van Soest, P.J., Robertson, J.B., Lewis, B.A., 1991. Methods for dietary fiber, neutral detergent fiber, and nonstarch polysaccharides in relation to animal nutrition, Journal of Dairy Science 74, 3583-3597. https://doi.org/10.3168/jds.S0022-0302(91)78551-2.

\section{Figures}

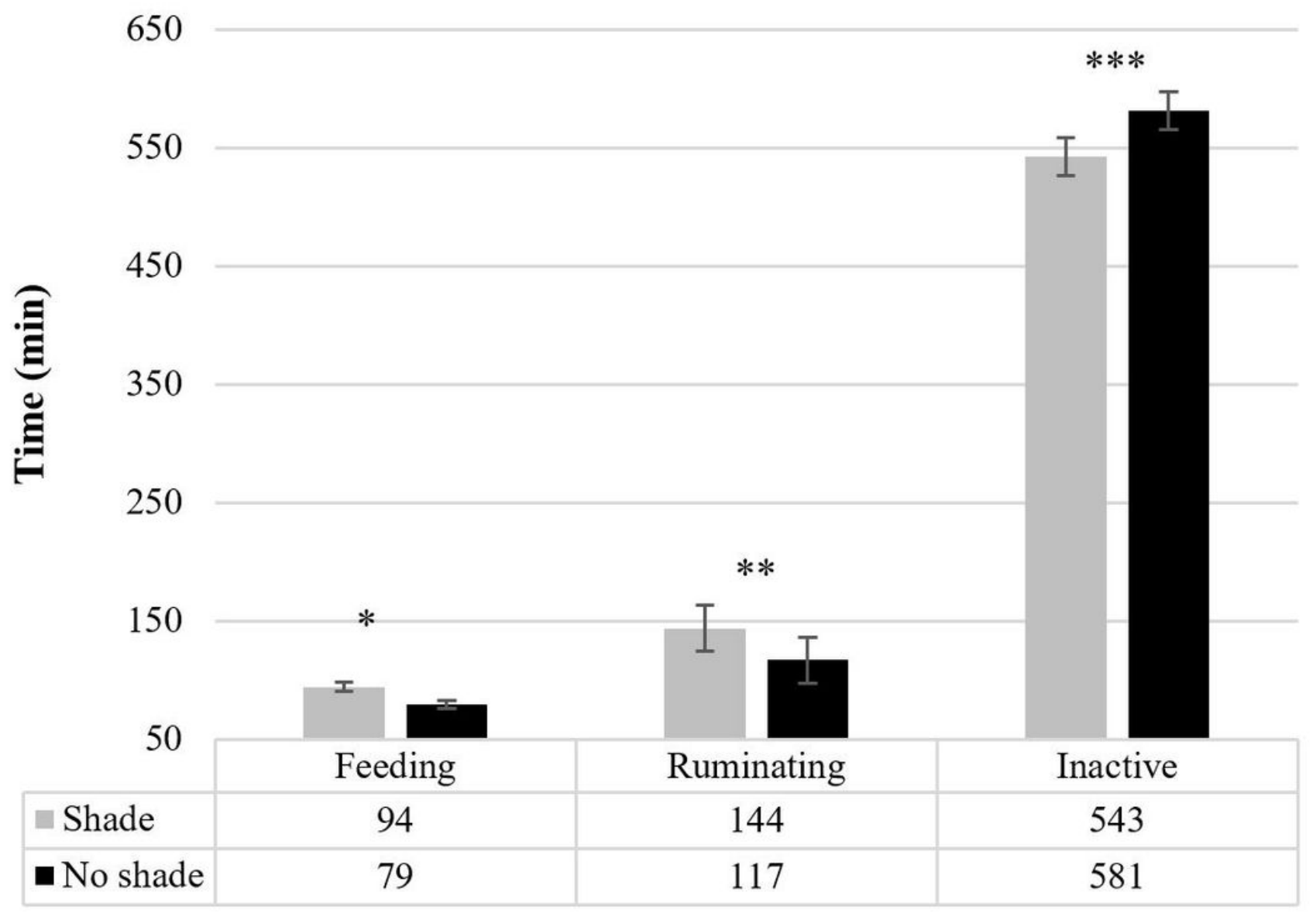

Figure 1 
Behaviour time (minute) in shaded and no shaded steers. ${ }^{*} \mathrm{P}<0.01 ;{ }^{* *} \mathrm{P}<0.001 ;{ }^{* * *} \mathrm{P}<0.0001$ (a)

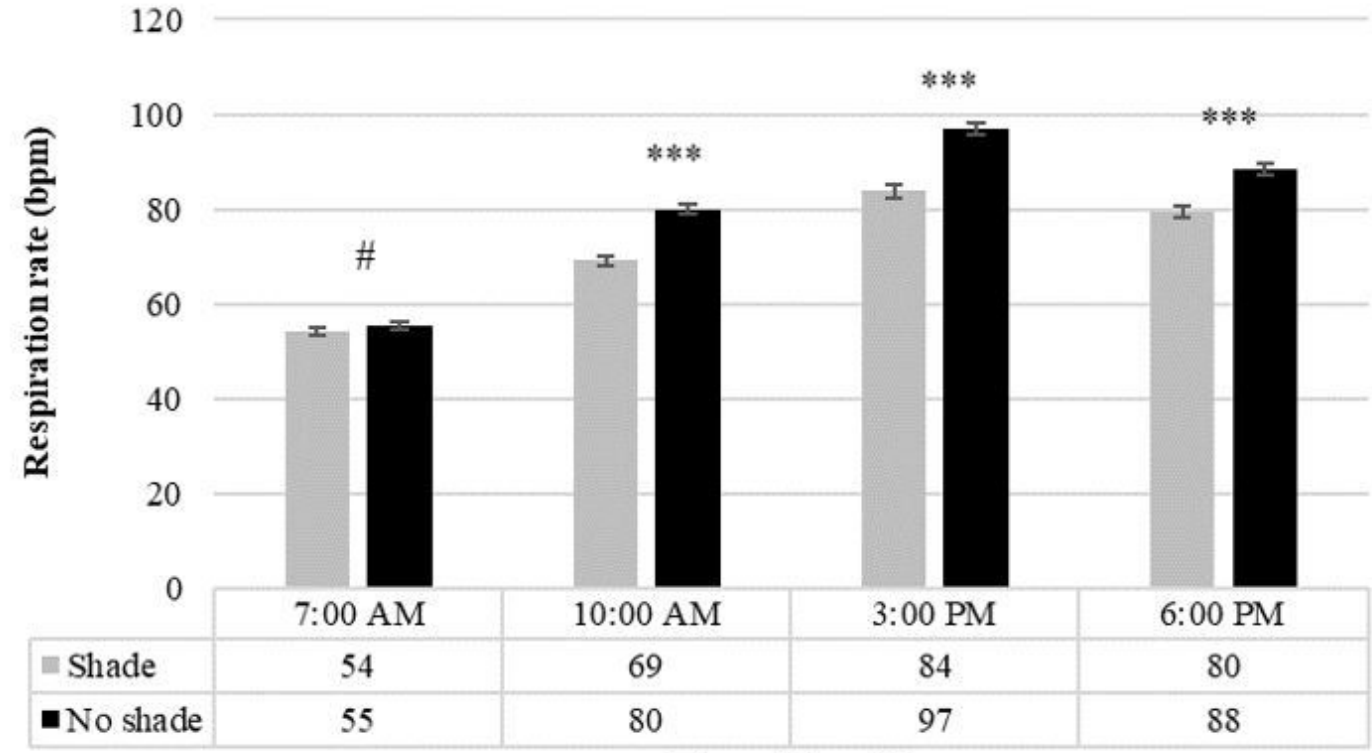

Time of day (h)

(b)

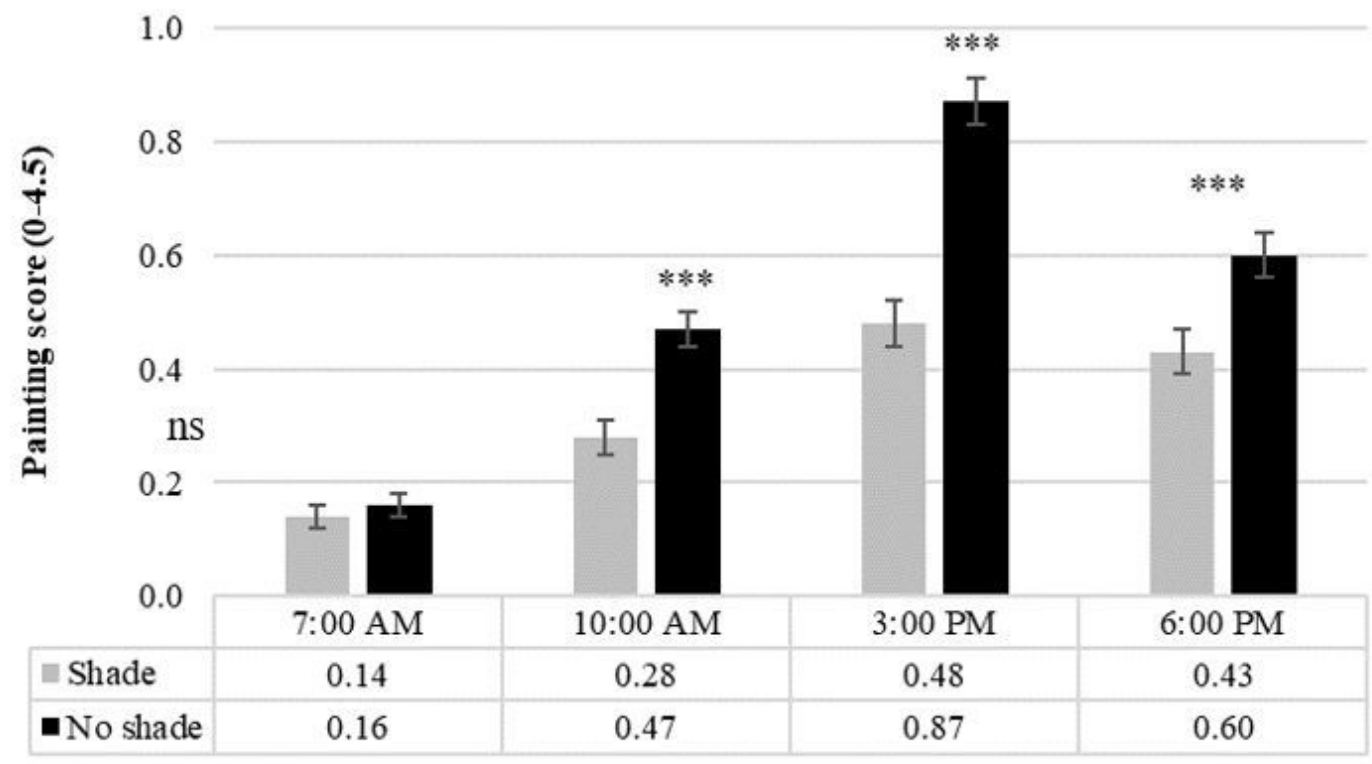

Time of day (h)

Figure 2

Mean respiration rate (RR; bpm) and mean painting score (PS; $0=$ no panting, animal under no heat load to $4.5=$ catastrophic stress, severely heat-stressed animal) of shaded and no shaded steers during daytime hours (time of day, hours). ns: no significant; \#P $<0.10 ; * \star \star P<0.0001$ 
(a)

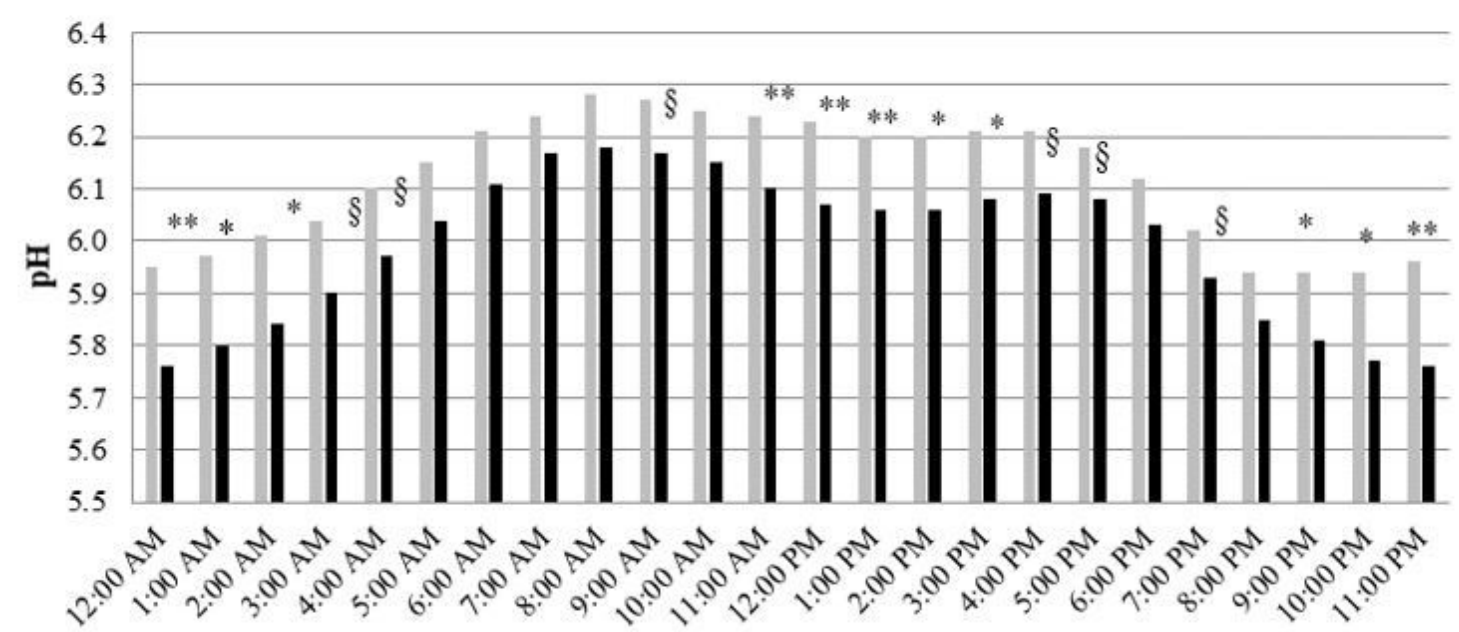

Time of day (h)

m Shade - No shade

(b)

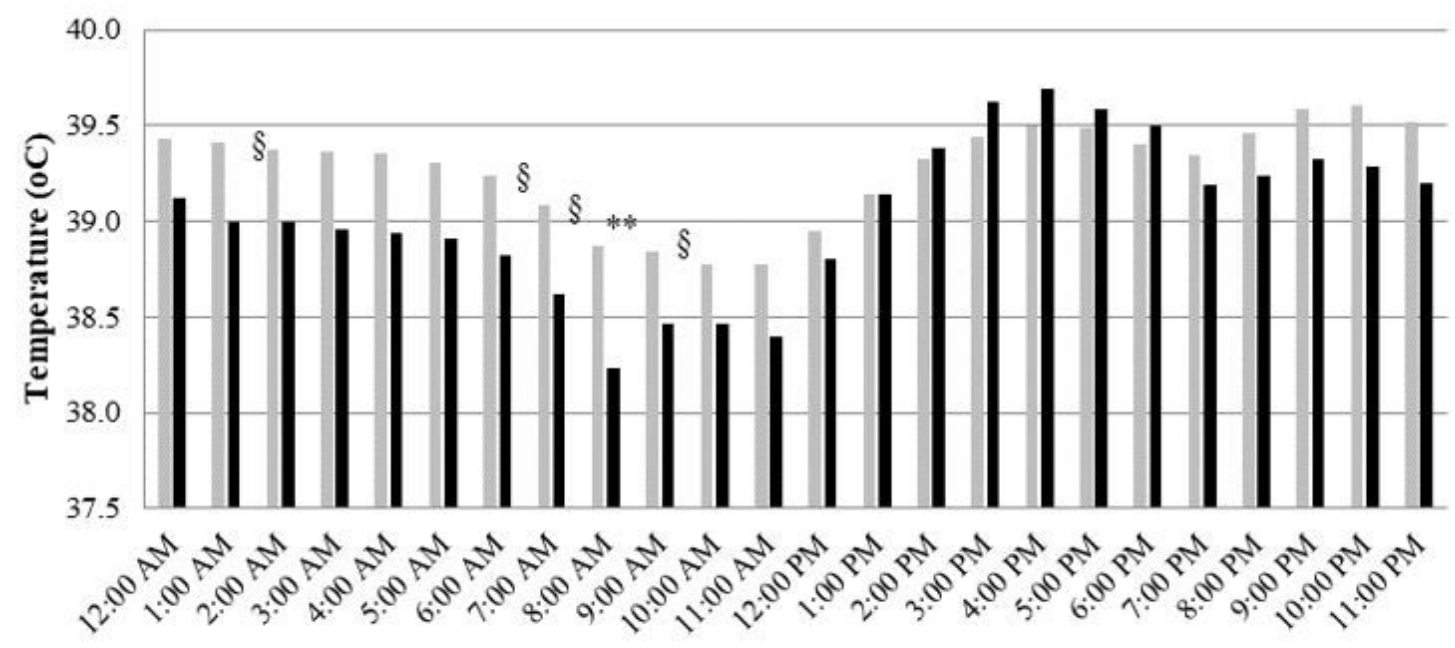

Time of day (h)

- Shade $\mathbf{m}$ No shade

Figure 3

Within-day response data for ruminal $\mathrm{pH}(\mathrm{a})$ and temperature (b) of shaded and no shaded steers during daytime hours (time of day, hours). §P $<0.05 ; * \mathrm{P}<0.01$; ${ }^{*} \mathrm{P}<0.001$

\section{Supplementary Files}


This is a list of supplementary files associated with this preprint. Click to download.

- Suppl.materialTAHPHeatstress.docx 